\title{
Effect of magnetic water on growth, yield and quality of groundnut infected with root-knot nematode (Meloidogyne arenaria) in sandy soil
}

\author{
Hozayn M. *; Korayem A.M. **; Mohamed M.M.M. ** and Abd EI Monem A.A. *** \\ * Field Crops Research; \\ ** Plant Pathology \& Nematology and \\ ${ }^{* * *}$ Botany Departments, Agriculture and Biology Division, National Research Centre, Dokki, Giza, Egypt. \\ Email Corresponding author: m_hozien4@yahoo.com
}

\begin{abstract}
Magnetic treatment is considered one of uncommon factor which has positive effects on yield of many crops. Two field trials using ground nut (var. Giza-6) were conducted at National Research Centre Experimental Station, Alimam Malek village, Al Nubaria district, Al Behaira Governorate, Egypt in 2014 and 2015 summer seasons to study and evaluate the effects of magnetizing irrigation water on growth, yield and quality of groundnut naturally infected with root-knot nematode (Meloidogyne arenaria) in sandy soil. Results indicated that, irrigation peanut plants with water passed through magnetic device (4 inch, production by Magnetic Technologies L.C.C., Russia, branch United Arab Emirates) induced positive significant effect on the most of studied parameters. The percentage improvement ranged between 5.10 to $43.05 \%$ in yield components. As well as, the increases reached to 30.38 and $29.46 \%$ in pods and seeds yield per hectar. Results also indicated that the nematode infection (root galling) was not significantly affected by magnetic water, while the number of the juveniles $\left(J_{2}\right)$ in soil at harvest (first nematode generation ) significantly increased in magntic water treatment compared with that in normal water.
\end{abstract}

Keywords: Groundnut, magnetized water, root-knot nematode, yield.

\section{Introduction}

Groundnut, Arachis hypogaea $L$. is cultivated in all six continents especially in subtropical and tropical countries. It is ranked $13^{\text {th }}$ among edible crop plants (Minton, 1984) and listed as one of 12 crop plants stand between man and starvation (Witter, 1981) as well as it is a high value cash crop. Its seeds are rich in calorie $(5.6 \mathrm{cal} / \mathrm{g})$ containing about $25 \%$ protein and have many utilization, may be used boiled, broiled, roasted, fried, ground into peanut butter or crushed for oil (Minton and Baujard, 1990). In Egypt cultivated area of ground nut has increased especially in the new reclaimed sandy soil, as the area increased from 20000 hectares in 2000 year to about 70000 ha in 2013 (Anon, 2015). Groundnut rootknot nematode, Meloidogyne arenaria is considered one of the most serious 
nematode pathogens of ground nut in many parts of the world attacking ground nut roots, pegs and pods causing substantial yield losses in severely infested fields (Minton and Baujard, 1990). Losses in peanut yield due to root-knot nematodes were varied according to plant cultivar, nematode population density and environmental conditions. It was ranged from $0.5 \%$ to $81.0 \%$ in the southern USA (Anon, 1987; Abdel Momen and Starr, 1997) about 15\% in west Africa and Southern Asia (Sasser, 1979), 70\% in subtropical and tropical regions (Lamberti, 1979), and about 20\% in Egypt (Korayen and Osman, 1994; Korayen and Bondok, 2013). Thus, many growers have applied many chemical nematicides for controlling nematode pathogens of groundnut. Many of these chemicals were found to be possible carcinogenic, incite male sterility and have many bad effects to the environment (Write, 1981; Johnson and Feldmesser, 1987; Thomason,1987; Rich et al., 2004).

New approaches for nematode management are to maintain nematode population density at level that do not cause economic damage and/or to increase the plant tolerance to nematode infection, in same time increase yield. Use of magnetic water in agriculture is a new approach for increasing the yield of many crops especially in sandy soil. Several studies reported that magnetic irrigation water treatments have been a positive effect on seed germination, plant growth and development, the ripening, yield and quality of many different tested crops (Aladjadjiyan A., 2010; Hozayn et al., 2013, 2014, 2015). The improving in germination, growth and yield of tested crops were accompanied with improvement in photosynthetic pigments (Hozayn and Amira, 2010 a \& b; Amira and Hozayn, 2010 a \& b; Hozayn et al., 2014 ), activates protein formation and enzymes activity (Atak et al., 2007; Çelik et al., 2009), induces cell metabolism and mitosis meristematic cells of pea, lentil, onion and flax (Belyavskaya, 2001; Hozayn et al., 2015).

Increasing in economic yield regarding application of magnetic water treatments under field condition reached to $144,8 \%$ in potato, (Marinkovic et al., 2002); pepper by $64,9 \%$ (Takac et al., 2002), soybean from 5 to $25 \%$, with a higher quantity of oil and protein and at sunflower from 13,2 to 17,3\% (Crnobarac et al., 2002), wheat by $6.3-10.6 \%$ (Kordas, 2002), broad bean and pea by 10 and $15 \%$, respectively (Podlesny et al., 2005), rice by 13-23\% (Tian et al., 1991). Also, the root mass,leaf surface and yield of sugar beet treated with magnetized water increased by $94.0 \%, 52.0 \%$ and $12.88 \%$,respectively (Vasilevski, 2003). Similar positive trends were obtained under Egyptian condition by Hozayn et al. (2013, 2014, 2015, 2016 and 2017), they reported that the percent of increase in economic yield (ton $\mathrm{ha}^{-1}$ ) in response to magnetized water application reached to $13.71 \%$ at wheat, $8.25 \%$ at faba bean, $21.8 \%$ at chick pea, $36.02 \%$ at canola, $22.37 \%$ at flax and $19.05 \%$ at sugar beet crop as compared to irrigation with ordinary water application.

In this work we study the impact of irrigation with magnetic water on yield and 
quality of ground nut naturally infected with root- knot nematode Meloidogyne arenaria in sandy soil.

\section{Materials and Methods}

Two field experiments were conducted during 2014-2015 summer seasons in sandy soil naturally infected with root knot nematode, Meloidogyne arenaria at National Research Centre Experimental Station, El-Nobaria regon, El-Beheira governorate, Egypt to study the effect of irrigation with magnetized water on growth, yield and quality of peanut and on the root knot nematode infection and reproduction.

Soil analysis:Physical and chemical properties of soil in which experiment was done were analyzed according to method of Chapman and Pratt (1978).

Nematode extraction and bioassay: At harvest peanut plants were removed by hands, then rondom samples (soil and roots) of 20 plants (replicates) were taken from each plot (treatment). The second stage juveniles $\left(\mathrm{J}_{2}\right)$ were extracted from soil samples by sieving method (Cobb,1918). The root knot nematode infection (gall index, GI)of each plant root was estimated as follows: 1=no galls, 2=1-25 \% root galling, $3=26-50 \%, 4=51-75 \%$ and $5=$ more than $75 \%$, root galling (Barker, 1985).

Table (1): Soil physical and chemical analysis.

\begin{tabular}{|c|c|c|c|}
\hline \multirow{2}{*}{ Parameters } & \multicolumn{2}{|c|}{ Soil depth } & \multirow{2}{*}{ Average } \\
\hline & $0-15$ & $15-30$ & \\
\hline \multicolumn{4}{|c|}{ Particle size distribution } \\
\hline Coarse sand & 48.2 & 54.75 & 51.5 \\
\hline Fine sand & 49.11 & 41.43 & 45.3 \\
\hline Clay + Silt & 2.69 & 3.82 & 3.2 \\
\hline Texture & Sandy & Sandy & sandy \\
\hline $\mathrm{PH}(1: 2.5)$ & 8.22 & 7.94 & 8.08 \\
\hline$E C\left(\mathrm{dSm}^{-1}\right)(1: 5)$ & 0.2 & 0.15 & 0.175 \\
\hline Organic matter (\%) & 0.67 & 0.43 & 0.55 \\
\hline \multicolumn{4}{|c|}{ Soluble cations (mq/l) } \\
\hline $\mathrm{Ca}^{++}$ & 0.6 & 0.5 & 0.55 \\
\hline $\mathrm{Mg}^{++}$ & 0.5 & 0.3 & 0.40 \\
\hline $\mathrm{Na}^{++}$ & 0.9 & 0.8 & 0.85 \\
\hline $\mathrm{K}^{+}$ & 0.2 & 0.1 & 0.15 \\
\hline \multicolumn{4}{|c|}{ Soluble anions (mq/l) } \\
\hline $\mathrm{CO}^{-3}$ & - & - & \\
\hline $\mathrm{HCO}^{-3}$ & 0.6 & 0.4 & 0.50 \\
\hline $\mathrm{Cl}^{-}$ & 0.75 & 0.7 & 0.73 \\
\hline $\mathrm{SO}^{-4}$ & 0.85 & 0.6 & 0.73 \\
\hline
\end{tabular}


Cultivation method and layout of experiment: Seeds of the groundnut(cv.Giza 6) were obtained from Legume Research Department, Field Crop Research Institute, Agriculture Research Centre, Giza, Egypt. Recommended rates of ground nut seeds were planted in plots $\left(10\right.$ length $^{\mathrm{m}} \times 10$ width $\left.^{\mathrm{m}}\right)$ at the first week of May in both seasons. The seeds were coated just before sowing with the bacterial inoculants, using Arabic gum (40\%) as adhesive agent and were sown in hills $10 \mathrm{~cm}$ apart. Control treatment was irrigated with normal water, while the other treatment (magnetized water) was irrigated with water after magnetization through passing a four inch Magnetic device [produced by Magnetic Technologies LLC PO Box 27559, Dubai, UAE]. Four replications were used in each treatment. The recommended NPK fertilizers for ground nut crop were applied through the period of experiment.

Phosphorus $\left(720 \mathrm{kgP}_{2} \mathrm{O}_{5} \mathrm{ha}^{-1}\right.$ as calcium superphosphate; $15 \% \mathrm{P}_{2} \mathrm{O}_{5}$ ) and potassium ( $58 \mathrm{~kg} \mathrm{~K}_{2} \mathrm{O}$ ha $^{-1}$; as potassium sulfate $48 \% \mathrm{~K}_{2} \mathrm{O}$ ) were added during seed bed preparation and after one month from sowing, respectively. While, nitrogen fertilizer (144 $\mathrm{kg} \mathrm{N} \mathrm{ha}^{-1}$ as ammonium sulfate $20.60 \% \mathrm{~N}$ ) was added in four equal doses weekly starting from 15 days after sowing. Sprinkler irrigation was applied as plants needed. The layout of experiment was shown in (Fig. 1). Groundnut was manually harvested on September $10^{\text {th }}$ and $14^{\text {th }}$ in the first and second season, respectively.

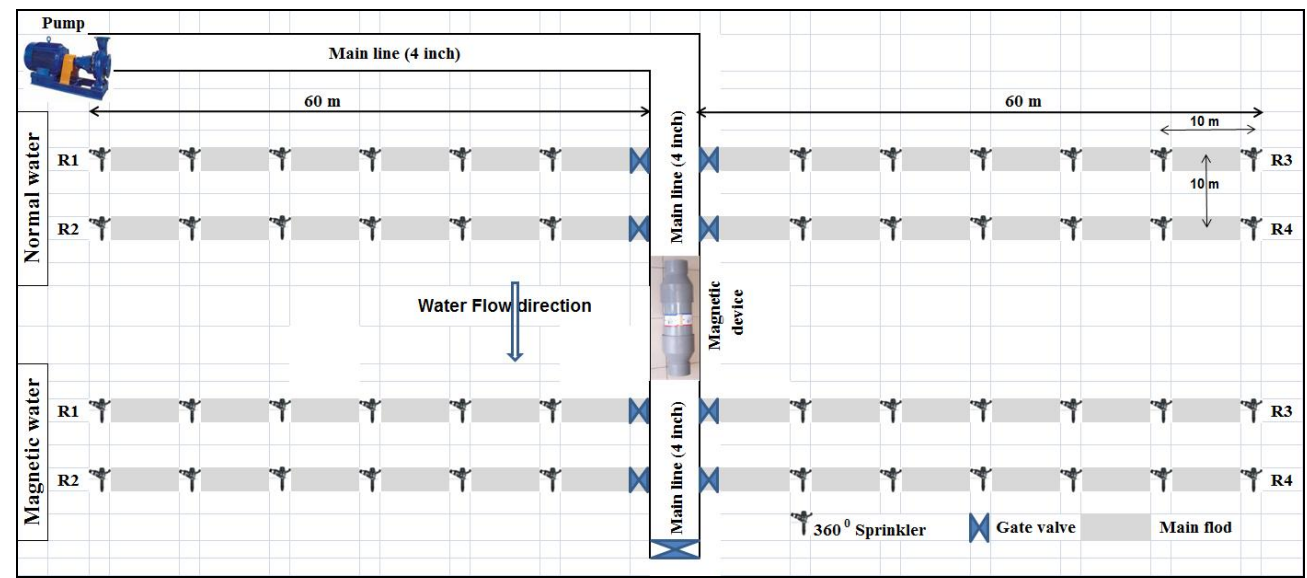

Fig. (1): Layout of experiment design under solid set sprinkler system.

Yield and yield component: At harvest, a random sample of 10 plants was taken from each plot to determine plant height $(\mathrm{cm})$, branches no. plant ${ }^{-1}$, number and weight of pods and seeds plant ${ }^{-1}, 100$-pods and seeds weight (g). Plants in the whole plots were harvested and their pods were air dried and threshed to calculate seed yield/ha. Shilling percentage was calculated as following equation: Shelling $(\%)=($ Seeds weight/ Pods weight $) \times 100$.

Seeds chemical analysis: The moisture content of the seed samples was determined by oven-drying to a constant weight at $105^{\circ} \mathrm{C}$. Oil $\%, \mathrm{~N}$, crude fiber and 
ash content were determined accordance with the standard methods of AOAC (2000). Carbohydrates (nitrogen free extract) were determined by difference. Seed protein content was calculated by multiplying total nitrogen concentration by 6.25 . Oil and protein yields/ha were calculated by multiplying seed yield by seed oil and protein percentage.

Statistical analysis: Statistical analysis was carried out using SPSS program Version 16. A student Independent $t$-test was carried out to find the significant differences between magnetic and nonmagnetic water treatments.

\section{Results and Discussion}

Soil analysis: Physical and chemical analysis of experimental soil is presented in Table (1). Data indicated that soil was sandy and slightly alkaline $(\mathrm{pH}=8.08)$, with relatively low organic matter $(0.55 \%)$ and low electric conductivity $\left(E_{c}=0.175\right)$.

Effect of magnetic water on groundnut growth and yield:Data presented in Table (2) indicated that irrigation peanut with magnetic water significantly increased its growth and yield compared with those of peanut irrigated with normal water.As plant height $(\mathrm{cm})$, number of branches and pods per plant, fresh and dry weight $(\mathrm{g})$, no. seed per plant, 100-seed and pod weight $(\mathrm{g})$ and shelling $\%$ increased in magnetic water treatment by $14.3 \%, 16.8 \%, 24.9 \%, 43.1 \%, 30.6 \%, 37.9 \%, 33.8 \%$, $3.7 \%, 49.9 \%$ and $5.1 \%$ respectively, compared to those in normal water one. Thus pod and seed yield (ton ha ${ }^{-1}$ )increased by $30.4 \%$ and $29.5 \%$, respectively.

Table (2): Effect of irrigation with magnetized and normal water on peanut growth and yield (Average of 2014 and 2015 seasons).

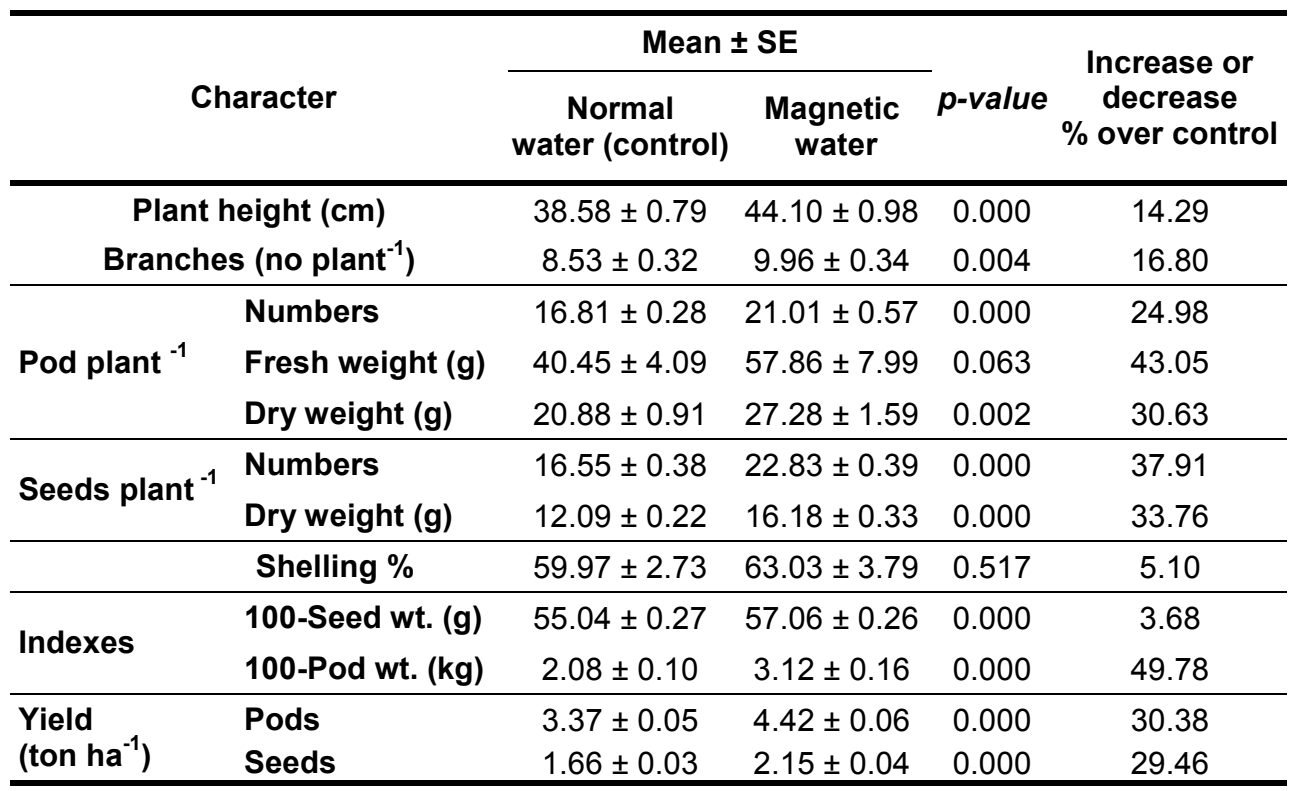

$P$-value $<0.05$ level is significant and $P$-value $>0.05$ is not significant according to Independent $t$-test. 
Effect of magnetic water on nematode infection and reproduction: Data presented in Table (3) indicated that nematode root galling(nematode infection) was slightly high (3.3) in magnetic water treatment compared to (2.9) in normal water one, still no significant differences $(p=0.05)$ between them was obtained. While number of scorned stage juveniles $\left(\mathrm{J}_{2}\right)$ in soil at peanut harvest (first nematode generation) was significantly increased in magnetic treatment (202) compared to (134) in normal water, as increasing over control was $50.7 \%$

Table (3): Effect of peanut irrigation with magnetized water on root knot nematode infestation and reproduction (Average of 2014 and 2015 seasons).

\begin{tabular}{lcccc}
\hline \multirow{2}{*}{ Nematode data } & \multicolumn{2}{c}{ Mean \pm SE } & p-value & $\begin{array}{c}\text { Increase \% } \\
\text { over control }\end{array}$ \\
\cline { 2 - 5 } & water (control) & $\begin{array}{c}\text { Magnetic } \\
\text { water }\end{array}$ & - & \\
\hline Root gall index (GI) & $2.90 \pm 0.16$ & $3.30 \pm 0.18$ & 0.105 & 13.79 \\
Stage $^{\text {2-nd }}$ juveniles (J2) & $134 . \pm 24.08$ & $202 . \pm 41.52$ & 0.004 & 50.74 \\
\hline
\end{tabular}

GI (root gall index) is average of 20 replicates, $\mathrm{J} 2$ in $200 \mathrm{~g}$ soil.

$P$-value $<0.05$ level is significant and $P$-value $>0.05$ is not significant according to Independent $t$-test.

\section{Chemical constituents in yielded seed:}

Dry samples of groundnut seeds were examined in percentage for moisture, dry and organic matter, crude protein, crude fiber, oil content, total carbohydrate and ash under irrigation with magnetic and ordinary water (Table 4). Data indicated that moisture, crude protein and crude fiber significantly increased in seeds of magnetic water compared to those of normal water. Increasing reached to $5.6 \%$, $2.24 \%$ and $11.0 \%$, respectively. While dry and organic matter, oil, carbohydrates and ash were not significantly effected.

Table (4): Effect of irrigation with magnetized water on chemical constitute of ground nut dry yielded seeds.

\begin{tabular}{|c|c|c|c|c|c|}
\hline & & \multicolumn{2}{|c|}{ Mean \pm SE } & \multirow[b]{2}{*}{ p-value } & \multirow{2}{*}{$\begin{array}{l}\text { Increase or } \\
\text { decrease } \\
\% \text { over control }\end{array}$} \\
\hline \multicolumn{2}{|c|}{ Character } & $\begin{array}{c}\text { Normal } \\
\text { water (control) }\end{array}$ & $\begin{array}{l}\text { Magnetic } \\
\text { water }\end{array}$ & & \\
\hline \multirow{8}{*}{ 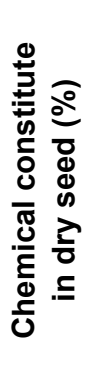 } & Moisture & $4.68 \pm 0.01$ & $4.94 \pm 0.07$ & $0.004^{*}$ & 5.63 \\
\hline & Dry matter & $95.27 \pm 0.03$ & $95.29 \pm 0.10$ & 0.866 & 0.02 \\
\hline & Organic mater & $97.59 \pm 0.03$ & $97.64 \pm 0.04$ & 0.328 & 0.05 \\
\hline & Crude protein & $26.69 \pm 0.05$ & $27.29 \pm 0.03$ & $0.000^{*}$ & 2.24 \\
\hline & Crude fiber & $4.27 \pm 0.06$ & $4.75 \pm 0.07$ & $0.000^{*}$ & 11.41 \\
\hline & Oil & $52.72 \pm 0.06$ & $51.99 \pm 0.20$ & 0.016 & -1.38 \\
\hline & Carbohydrates & $13.85 \pm 0.03$ & $13.83 \pm 0.05$ & 0.736 & -0.14 \\
\hline & Ash & $2.41 \pm 0.03$ & $2.47 \pm 0.05$ & 0.297 & 2.63 \\
\hline
\end{tabular}

$P$-value $<0.05$ level is significant and $P$-value $>0.05$ is not significant according to Independent $t$-test. 
The present results suggested that irrigation of peanut with magnetic water increased its growth and yield and improved seed quality (Crude protein and fiber). These results are in harmony with those obtained by studies done on wheat, faba bean, canola, lentil and chick pea (Hozayen et al., 2014, 2015, 2016, 2017). A similar trend was obtained by Vashisth and Nogarajan (2008), Shabrangi and Majd (2009) on chick pea and lentil, respectively. Increasing peanut yield may be attributed to the stimulatory effect of magnetic water on photosynthetic pigment and on growth promoters., Adding magnetic water to soil may also influence soil $\mathrm{PH}$ changing it from slightly alkaline to slightly acidic, thus solubility of micronutrients be increased around peanut roots improving its nutritional status. Results also indicated that yield of peanut infected with nematodes increased in magnetic water treatment compared to that of peanut infected with nematodes and irrigated with normal water. In other word, yield of peanut increased in magnetic water regardless of nematode infection. This may be attributed to improve the nutritional status of peanut at magnetic water, thus increasing tolerance of peanut to nematode infection. Increasing the nematode juveniles $\left(\mathrm{J}_{2}\right)$ at harvest in the soil of magnetic water treatment may be also due to improve the nutritional status of plants supplying nematodes with more food, thus nematode females ( parents) lay more eggs and progeny.

\section{Conclusion}

Data obtained in the present work indicated that irrigation of peanut plants with magnetic water increased peanut growth and yield, regardless of root -knot nematode infection. Also the effect of magnetic water on the nematode infection was not significant.

\section{Acknowledgement}

This work was funded by The National Research Centre through the local project entitled "Application of magnetic technology for improving field crops under Egyptian Agriculture (2013-2018). The principal investigator Prof. Dr. Mahmoud Hozayn.

\section{References}

Abdel- Momen S.M. and Starr J. L. (1997). Damage functions for three Meloiogyne species on Arachis hypogaea in Texs. J. Nematol., 29: 478482.

Aladjadjiyan A.(2010). Influence of stationary magnetic field on lentil seeds.Int. Agrophys.,24, 321-324.

Amira M.S. Abd El-Qodos and Hozayn M. (2010a). Magntic water technology, a novel tool to increase growth, yield, and chemical constiuents of lentil (Lens esculenta) under greenhouse condition. Amer.-Eurasian J. Agric. \& Envir. Sci., 7(4): $457-462$. 
Amira M.S. Abd El-Qodos and Hozayn, M., (2010b). Response of growth, yield, yield components and some chemical constituent of flax for irrigation with magnetized and tap water. World Appl. Sci. J. 8(5), 630 - 634.

Anon (1987). Bibliography of estimated crop losses in the United States due to plant parasitic nematodes. Annals of Applied Nematology, a Supplement to the Journal of Nematol., 1:6-12.

AOAC (2000). Official Methods of Analysis, $17^{\text {th }}$ Ed. Association of Official Analytical Chemists,Washington, DC, USA.

Atak Ç.; Çelik Ö.; Olgun A.; Alikamanoglu S. and Rzakoulieva A. (2007). Effect of magnetic field on peroxidase activities of soybean tissue culture. Biotechnol. Biotechn. Equip., 21(2),166-171.

Barker K.R. (1985). Nematode extraction and bioassays. Pp 19-35 in K.R. Barker, C.C. Carter and J.N. Sasser (eds). An Advanced Treatise on Meloidogyne, Volume 2. Methodology. North Carolina State University Graphics.

Belyavskaya N.A. (2001). Ultrastructure and calcium balance in meristem cells of pea roots exposed to extremely low magnetic field. Adv. Space Res., 28: (4), 645-650.

Çelik Ö.; Büyükuslu N.; Atak Ç., and Rzakoulieva A. (2009). Effects of magnetic field on activity of superoxide dismutase and catalase in Glycine max (L.) Merr. Roots, 18(2), 175-182.

Chapman H.O. and Pratt P.E., (1978). Methods of Analysis for Soils, Plants and Water. Univ. of California Agric. Sci. Priced Publication, 4034. pp: 50.

Cobb N.A. (1918). Estimating the nema population of the soil. Agric. Tech. Circ. Bur. PI. Ind. U.S. Dept. Agric. No.1. 48 pp.

Crnobarc J.; Marinkovic B.; Tatic M. and Malesevic M., (2002). The effect of REIS on start up growth and seed yield of sunflower and soybean. Biophysics in agriculture production. University of Novi Sad, Tampograf.

Hozayn M.; Abd El-Monem A.A. and Abdelraouf R.E. (2013). Magnetic technology, a novel tool for correction ground water and improving crops and water productivity. The first international conference "Water desalination in the Arab world", 26 May, 2013, Cairo, Egypt

Hozayn M., and Amera M.S. Abd El-Qodos (2010a). Magnetic water application for improving wheat (Triticum aestivum L.) crop production. Agric. and Biol. $\mathrm{J}$ of North America, 1(4), 677- 682.

Hozayn M. and Amera M.S. Abd El-Qodos (2010b). Irrigation with magnetized water enhances growth, chemical constituent and yield of chickpea (Cicer arietinum L.). Agric. and Biol. J of North America, 1(4), 671 - 676. 
Hozayn M.; Abd El-Monem A.A.; Abdelraouf R.E. and Abdalla M.M., (2013 a). Do Magnetic Water affect Water Use Efficiency, Quality and Yield of Sugar Beet (Beta vulgaris L.) plant under arid regions conditions. J. Agronomy, 34(1), 1-10.

Hozayn M.; Abdel-Monem A.A; Elwial T.A. and Abdalla M.M. (2014). Future of magnetic agriculture in arid and semi-arid regions. Series A. Agronomy, Vol. LVII, 197- 204.

Johnson A.W., and J. Feldmesser. (1987). Nematicides - A Historical Review. Pp. 448-454 In: J.A. Veech and D.W. Dickson, eds. Vistas on Nematology. Society of Nematologists, Inc. Hyattsville, MD.

Korayem A. M. and Osman. R.O. (1994). Effect of sulphur and nematicides combination on root- knot nematode, yield and oil content of peanuts. Bull. Nat. Res. Centre, Egypt. 19 (4): 295-300.

Korayem A.M. and Moawad M.M.M. Bondok (2013). Damage threshold of rootknot nematode Meloidogyne arenaria on peanut in relation to date of planting and irrigation system. Canadian Jour. Plant Protection, 1 (3): 115122.

Kordas L. (2002). The effect of magnetic field on growth, development and the yield of spring wheat. Polish J. of Environmental Studies, 11 (5), 527-530.

Lamberti F. (1979). Econmic importance of Meloidogyne spp. in subtropical and Mediterranean climates. Pp. 341-357. In: Root - knot nematodes (Meloiogyne species): Systematics, Biolgoy and Control (Lamberti F. \& Taylor C.E., eds), London, New Yourk, San Francisco. Academic press.

Marinkovic B.; Ilin Z., Marinkovic J.; Culibrk M. and Jacimovic G. (2002). Potato yield in function variable electromagnetic field. Biophysics in agriculture production. University of Novi Sad, Tomograf.

Minton N. A. and Baujard P. (1990). Nematode parasite of peanut. Pp: 285-320. In: Plant Parasitic Nematodes in Subtropical and Tropical Aagriculture (M. Luc, R.A. Sikora \& J. Bridge, eds). CAB. International Inst. Parasitology. Wallingford Oxon. UK.

Minton N.A. (1984).Nematode parasites of peanuts. In Nickle, R.W. (Ed.).Plant and insect nematodes. New York, USA, Marcel Inc.PP: 373-394

Podlesny J.; Pietruszewski S. and Podlesna, A. (2005). Influence of magnetic stimulation of seeds on the formation of morphological features and yielding of the pea. Int. Agrophysics, 19, 1-8.

Rich J. R.; Dunn R. A. and Noling J W.( 2004). Nematicides: Past and Present Uses. Pp. 1179-1200 in Z. X. Chen, S. Y. Chen, and D. W. Dickson, eds. Nematology advances and perspectives vol.2: Nematode management and utilization. Wallingford, CT: CABI Publishing. 
Sasser J. N. (1979). Economic importance of Meloidogyne in tropical countires. Pp. 359-374. In: Root - Knot. Nematodes (Meloidogyne species): Systematics, Biology and Control (Lamberti F. \& Taylor C.E., eds). London, New Yourk, San Francisco, Academic pres.PP:469-476.

Shabrangi A. and Majd A. (2009). Effect of magnetic fields on growth and antioxidant systems in agricultural plants. PIERS Proceedings, Beijing, China, March, 23-27.

Takac A.; Gvozdenovic G. and Marinkovic B. (2002). Effect of resonant impulse electromagnetic stimulation on yield of tomato and pepper. Biophysics in Agriculture Production, University of Novi Sad, Tampograf.

Thomason I. J. (1987). Challenges Facing Nematology: environmental risks with nematicides and the need for new approaches. In J.A. Veech and D.W. Dickson (eds) Vistas on Nematology.PP469-476.Society of Nematologists. Hyettsville, Maryland, USA.

Tian W.X.; Kuang Y.L., and Mei Z.P. (1991). Effect of magnetic water on seed germination, seedling growth and grain yield of rice. Field Crop Abstracts, 044-07228.

Vashisth A. and Nagarajan S. (2008). Exposure of seeds to static magnetic field enhances germination and early growth characteristics in chickpea (Cicer arietinum L.). Bioelectromagnetics, 29(7), 571-578.

Vasilevski G. (2003). Perspectives of the application of biophysical methods in sustainable agriculture. Bulg. J. Plant Physiol., Special Issue, 179-186

Wittwer S.H. (1981). The 20 corps that stand between man and starvation. Farm chemicals, 144: 17-28.

Wright D.J. (1981). Nematicides: Mode of action and new approaches to chemicals control. pp 421-449. In: Plant parasitic nematodes, Vol.3. B.M. Zuckeerman and R.A. Rhodes (eds). New York: Academic Press. 


\section{الملخص العربي}

تأثير المياه الممغنطة على نمو وإنتاج وجودة الفول السوداني المصاب بنيماتودا تقعد الجذور في التربة الرملية

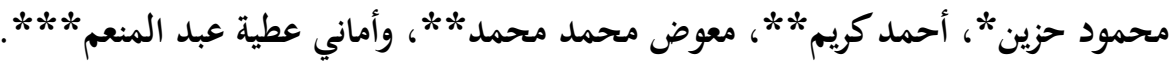

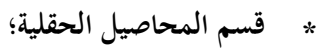

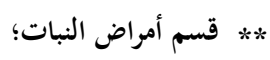

**** قسم النبات - وحدة البحوث الزراعية والبيولوجي - المركز القومي للبحوث - الدقي- جيزة - مصر.

أجريت هذه الدراسة بمحطة النوبارية بالإمام مالك محافظة البحيرة لمعرفة تأثير المياه

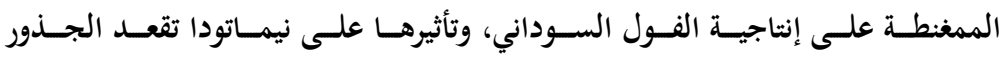

(Meloidogyne arenaria)

$$
\text { وتقييم الري الممغنط، وقد أوضحت النتائج ما يلي: }
$$

ري الفول السوداني بالمياه الممغنطة وجد أن هناك علاقة معنوية في المعاملة التي رويت

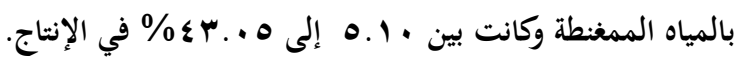

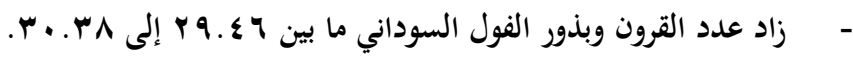

- أيضًا أوضحت النتائج أن نيماتودا تعقد الجذور لم تتأثر تأثيرًا معنويًّا بالمياه الممغنطة بينما

الكثافة العددية في التربة الطور اليرقي الثاني تأثر معنويًّا مقارنة بالمياه الطبيعية.

الكلمات الدالة: فول سوداني - نيماتودا تعقد الجذور - مياه طبيعية - مياه ممغنطة. 